\title{
Effect of G2548A polymorphism in the leptin gene on the BMI level in human population
}

\author{
Candráková, Kristína-Trakovická, Anna \\ Slovak University of Agriculture in Nitra, Faculty of Agrobiology and Food Resources, \\ Department of Genetics and Breeding Biology, Nitra, Slovakia \\ kristina.candrakova@gmail.com
}

SUMMARY

The polymorphism in leptin (LEP 2548A) seems to influence obesity among others genes. The aim of this study is to investigate the effect of the G2548A polymorphism on body mass index. We included 79 people from Slovakia with some genetic relatedness and used barrels kit to isolate the genomic DNA from an adenoblast swab-from the salivary. PCR products were amplified by pursued polymorphisms and G2548A, we restriction-analyzed them and then we identified the specific fragments describing the presence of chosen SNP polymorphism by the agarose electrophoresis, to analyze SNP polymorphism by PCR-RFLP method.

The LEP gene had increased frequency of $G$ allele (0.5506). The most common genotype occurring in the gene LEP was heterozygous genotype (AG) and the least frequent genotype in LEP was AA (0.1899). Taking the age into account the BMI is higher if the $G$ allele occurs in the LEP gene. Moreover, if the G allele genotype was situated in dominant form, then the highest average BMI was present.

According to the results we can assume that the AA genotype (LEP) has a protective effect on the prevalence of obesity compared to the other genotypes.

Keywords: obesity, body mass index, LEP, G2548A polymorphism

\section{INTRODUCTION}

The increase in the prevalence of obesity is a global trend in adults, as well as in children. A number of nutrition factors, or those of non-nutritive origin, should be taken into account when studying obesity instead of just one. With increasing knowledge of genetics and genomics, the inheritance of certain characteristics and factors rights in relation to obesity becomes increasingly important

All coherences and demonstrations cannot be associated with inborn quality only, since obesity is affected by a number of factors, which can influence the genetic predisposition by a large extent.

World Health Organization (WHO) characterizes obesity as "excessive or abnormal fat accumulation that presents a risk to health." Prevalence of overweight and obesity not only in adults but also in children population still increased strongly, as shown by the extensive study MONICA (Monitoring of Trends and determinants in cardiovascular diseases) carried out in many countries. Therefore, $\mathrm{WHO}$ has recognized obesity as the global obesity epidemic in 1997. For this reason, overweight and obesity should be taken as a serious disease of chronic nature, requiring extensive diagnostic and therapeutic procedures aimed in the long term with regard to the individual (Kunešová et al. 2005).

The most common and fastest method of determining obesity is to calculate body mass index (BMI - Body Mass Index, Quetelet index). It is characterized by dividing the weight in kilograms over the height in meters squared $\left(\mathrm{kg} \mathrm{m}^{-2}\right)$. This value can be used to classify underweight, normal weight, overweight, or obesity in adults as shown in Table 1.

Increasingly, genetic predisposition to weight gain combines the influence of the environment, which is undeniable, and therefore we talk about epigenetic factors. Even the development stage of the fetus in the uterus can sometimes lead to nutritional imbalance, and thus a change in the intrauterine environment and to changes in expression of genes with changes in DNA/ or methylation of histones (fetal programming), which may also lead to a predisposition to chronic diseases, such as obesity (Paquot et al. 2012).

The weight of the mother before or during pregnancy can also be a key factor in short-term and long-term risk of childhood obesity. Moreover, there are other parental factors that may increase the risk of obesity in children, for example: smoking mothers and their working time. The current lifestyle changes are important influences that lead to childhood obesity. These changes include increasing the number of sedentary activity, unhealthy eating habits and poor quality of sleep (Nyin Ang et al. 2012).

Kumar et al. (2010) found that children whose parents suffer from obesity $(32.7 \%)$ have a 25.2 times greater chance of developing obesity than children whose parents do not. When the father is obese, the son has 6.5 times the daughter 40.1 times higher chance of obesity in comparing with the control group. Conversely, maternal obesity affects $23.7 \%$ of boys and only $16 \%$ of girls. Therefore, we can say that obesity in children is significantly influenced by genetic factors and obesity of parent was most pronounced in paternal obesity, especially among girls. Not only the obesity of parents, but also the actual increase in BMI is associated with the development of obesity in children. It may be possible that with the improvement of environmental factors affecting the parents, one could reduce the risk of obesity in children.

Genomic studies (GWAS) identified genetic variants associated with body mass index (BMI). Genetic risk score (GRS) was positively associated with BMI ( $p=$ $0.012)$ and waist circumference $(\mathrm{p}=0.038)$. Interactions with GPS n-3 PUFA governing the association of adiposity are more than twice the phenotypic variability compared to the individual GPS. It appears that the intake of n-3 PUFAs has "anti-obesity" effect, which depends, in part, on the genetic predisposition of an individual to obesity (Lemas et al. 2013). 
The International classification of underweight, overweight and obesity in adults in view to BMI

\begin{tabular}{lcc}
\hline \multicolumn{1}{c}{ Classification } & BMI $\left(\mathrm{kg} \mathrm{m}^{-2}\right)$ & Additional definition \\
\cline { 2 - 3 } Underweight & Key definition & $<18.50$ \\
Severe thinness & $<18.50$ & $<16.00$ \\
Central thinness & $<16.00$ & $16.00-16.99$ \\
Mild thinness & $16.00-16.99$ & $17.00-18.49$ \\
\hline Normal range & $17.00-18.49$ & $18.50-22.99$ \\
\hline Overweight & $18.50-24.99$ & $23.00-24.99$ \\
Moderate obesity type & $\geq 25.00$ & $\geq 25.00$ \\
Obesity & $25.00-29.99$ & $25.00-27.49$ \\
Obesity type I & $\geq 30.00$ & $27.50-29.99$ \\
& $30.00-34.99$ & $\geq 30.00$ \\
Obesity type II & & $30.00-32.49$ \\
Obesity type III & $35.00-39.99$ & $32.50-34.99$ \\
\hline
\end{tabular}

Source: WHO (1995, 2000, 2004)

The studies of leptin gene often results in their focus on the frequency between the genotypes, compared to the level of leptin or triglycerides in the blood and with body mass index (BMI). Constantin et al. (2010) examined gene polymorphisms G2548A and LEP-LEPR-Q223R. The regression analysis found that taking into account the age, sex, and BMI involved pointing genotype GG (LEP) at increased risk of developing obesity $(p=0.013)$ and also the $G$ allele carriers had significantly higher leptin. Carriers of allele R (LEPR) had higher levels of triglycerides, glucose and increased systolic and diastolic blood pressure. Generally, however, there was no evidence of genetic risk factors in the study population of Romania.

Similar results demonstrated also Ali et al. (2009), when they investigated the impact of gene polymorphism G2548A LEP. They showed that women with obesity in Tunisian population, which were carriers of the A allele had a significantly lower leptin levels. A positive effect of allele polymorphism has been observed in the levels of leptin as confirmed by Fourati et al. (2013).

\section{MATERIAL AND METHODS}

The target group consisted of people with different age structures and with certain genetic similarity, which created relatedness between individuals. Because of the formation of a general examination of overweight and obesity in humans, there were 79 people evaluated from which 74 belonged to 14 families, and five people form a single group, without inclusion of a particular family.

For reasons of privacy, the individual families are designated by letters of the alphabet $(\mathrm{A}-\mathrm{N})$. Group without genetic similarity was designated by the letter X.
Genomic DNA was isolated from the adenoblast swabs using a commercial kit Qiagen DNA Mini Kit (Qiagen). SNP analysis of genes LEP polymorphism (G2548A) was performed using molecular genetic PCR-RFLP method. PCR amplification products observed polymorphism G2548A and subsequent restriction analysis was carried out following the methodology Mammès et al. (2000) and Deeparani et al. (2009). Identification of specific restriction fragment describing the presence of different alleles of the selected SNP polymorphisms was performed by agarose gel electrophoresis.

Age, height and weight were assessed in the target group, and then the body mass index (BMI) was calculated according to the following formula:

$$
\mathrm{BMI}=\text { weight }(\mathrm{kg}) / \text { body height }{ }^{2}(\mathrm{~m})
$$

Basic statistical analysis of gene polymorphism was performed by the following relationships:

1. Alleles frequencies for double allelic system according to the Hardy-Weinberg law

$$
\begin{aligned}
& \mathrm{p}_{\mathrm{A}}=(2 \cdot \mathrm{AA}+\mathrm{AB}): 2 \mathrm{~N} \\
& \mathrm{q}_{\mathrm{B}}=(2 \cdot \mathrm{BB}+\mathrm{AB}): 2 \mathrm{~N}
\end{aligned}
$$

where $\mathrm{p}_{\mathrm{A}}, \mathrm{q}_{\mathrm{B}}$ - the frequency of each allele, $\mathrm{N}$ - total number of individuals.

2. Genotypes frequencies according to the HardyWeinberg law

$$
\left(\mathrm{p}_{\mathrm{A}+} \mathrm{q}_{\mathrm{B}}\right)^{2}=\mathrm{p}_{\mathrm{A}}^{2}+2 \mathrm{p}_{\mathrm{A}} \mathrm{q}_{\mathrm{B}}+\mathrm{q}_{\mathrm{B}}^{2}=1
$$


3. Genotypic balance was verified by $\chi^{2}$-test

$$
\chi_{(n-1)}^{2}=\sum \frac{(e-t)^{2}}{t}
$$

where $\mathrm{n}$ - total number of phenotypic classes, e observed number of genotypes, $\mathrm{t}$ - theoretical number of genotypes.

4. The polymorphic information content (PIC) of Botstein et al. (1980)

$$
P I C=1-\sum\left(p^{2}+q^{2}\right)-\left(\sum_{i=1}^{n-1} \sum_{j=i+1}^{n} 2 p_{i}^{2} p_{j}^{2}\right)
$$

5. Heterozygosity $\left(\mathrm{H}_{\mathrm{e}}\right)$ by Nei (1978)

$$
\mathrm{H}_{\mathrm{e}}=1-\sum\left(\mathrm{p}^{2}-\mathrm{q}^{2}\right)
$$

The relationship of body mass index (BMI) and the polymorphism studied genes was analyzed on the basis of a linear model:

$$
\mathrm{BMI}_{\mathrm{ijk}}=\mu+\mathrm{POHL}_{\mathrm{i}}+\mathrm{LEP}_{\mathrm{j}}+\mathrm{b}(\mathrm{age})_{\mathrm{ijk}}+\mathrm{e}_{\mathrm{ijk}}
$$

where BMI - body mass index, $\mu$ - mean value, $\mathrm{POHL}_{i}$ - fixed effect of sex, $\mathrm{LEP}_{\mathrm{j}}$ - fixed effect of genotype (gene LEP), b(age $)_{\mathrm{ijk}}$ - effect of age in the form of linear regression, $e_{i j k}-$ residual effect.

Laboratory processing of samples and the DNA analyzes were carried out at the Department of Genetics and Animal Breeding Biology, Slovak University of Agriculture in Nitra. Statistical analysis was performed the program SAS Enterprise Guide 4.2 and the program SAS 9.2. The average value of individual families relatedness were calculated based on analysis of pedigree information using a software package CFC ver. 1.0 .

\section{RESULTS}

\section{Analysis of frequency and basic statistical characteristics}

The group consisted of 79 people of different age structures, usually with a known family relatedness, including 48 women and 31 men.
These people accounted for a total of 14 families identified anonymously by letters from A to N. Four people were included in the group $\mathrm{X}$, as there were no familial relationships with other individuals (Table 2).

High average relatedness values indicate relatively narrow familial relationships between individuals, within families (Table 1). Most often it was a relationship of parent and offspring, respectively, and family ties between full siblings (relatedness coefficient values are 0.5 ). The values above are particularly important in terms of performed genetic analysis of individual genes. The probability of transmission of risk allele's parents to offspring could be $50 \%$ if a parent has one risk allele, or $100 \%$ if a parent has both risk alleles. Genetic analysis in the human field is often based on a common analysis of parents and their offspring.

Table 2 .

Abundance of people and the average relatedness by families

\begin{tabular}{lrrccc}
\hline Family & Count & Men & Women & Relatedness* & Relatedness** \\
\hline A & 13 & 5 & 8 & 0.3500 & 0.1350 \\
B & 6 & 3 & 3 & 0.5000 & 0.3000 \\
C & 3 & 1 & 2 & 0.5000 & 0.3330 \\
D & 5 & 2 & 3 & 0.4375 & 0.1750 \\
E & 6 & 2 & 4 & 0.4091 & 0.3000 \\
F & 6 & 3 & 3 & 0.5000 & 0.3000 \\
G & 7 & 1 & 6 & 0.4063 & 0.1550 \\
H & 4 & 2 & 2 & 0.4375 & 0.2920 \\
I & 4 & 0 & 4 & 0.3750 & 0.3750 \\
J & 3 & 1 & 2 & 0.4167 & 0.4160 \\
K & 3 & 1 & 2 & 0.5000 & 0.3330 \\
L & 10 & 5 & 5 & 0.4063 & 0.3610 \\
M & 2 & 1 & 1 & 0.5000 & 0.5000 \\
N & 3 & 2 & 1 & 0.5000 & 0.3330 \\
X & 4 & 2 & 2 & - & - \\
Overall & 79 & 31 & 48 & 0.4456 & 0.3077 \\
\hline
\end{tabular}

Note: relatedness $*$ - average relatedness of related individuals in the family, relatedness $* *$ - the average relatedness of all individuals in the family

Table 3-4 are the basic statistical characteristics of the analyzed indicators of the first group of people. The classification of individuals analyzed according to the international classification of overweight, overweight and obesity are presented in Table 5 .

The basic statistical characteristics

\begin{tabular}{llrrrrr}
\hline \multicolumn{1}{c}{ Gender } & & Indicator & Mean & \multicolumn{1}{c}{$\mathrm{s}_{\mathrm{x}}$} & \multicolumn{1}{c}{ Min. } & \multicolumn{1}{c}{ Max. } \\
\hline \multirow{2}{*}{ Men } & Weight $(\mathrm{kg})$ & 80.85 & 23.21 & 14.00 & 128.00 & 31 \\
& Height (m) & 1.71 & 0.20 & 0.88 & 1.91 & 31 \\
& BMI $\left(\mathrm{kg} \mathrm{m}^{-2}\right)$ & 27.09 & 5.35 & 18.08 & 39.51 & 31 \\
& Age (year) & 42.29 & 20.82 & 2.00 & 79.00 & 31 \\
\hline Women & Weight (kg) & 69.23 & 18.29 & 12.00 & 113.00 & 48 \\
& Height (m) & 1.64 & 0.14 & 0.98 & 1.80 & 48 \\
& BMI (kg m $\left.{ }^{-2}\right)$ & 25.37 & 5.99 & 11.15 & 43.06 & 48 \\
& Age (year) & 38.65 & 18.42 & 2.00 & 74.00 \\
\hline
\end{tabular}


The basic statistical characteristics (minimal age - 20)

\begin{tabular}{llrrrrr}
\hline \multicolumn{1}{c}{ Gender } & \multicolumn{1}{c}{ Indicator } & Mean & \multicolumn{1}{c}{$\mathrm{s}_{\mathrm{x}}$} & \multicolumn{1}{c}{ Min. } & \multicolumn{1}{c}{ Max. } \\
\hline Men & Weight $(\mathrm{kg})$ & 87.80 & 15.49 & 64.00 & 128.00 & 26 \\
& Height (m) & 1.77 & 0.07 & 1.55 & 1.91 & 26 \\
& BMI (kg m $\left.{ }^{-2}\right)$ & 28.10 & 4.87 & 21.14 & 39.51 & 26 \\
& Age (year) & 48.65 & 16.00 & 20.00 & 79.00 & 26 \\
\hline Women & Weight (kg) & 73.00 & 12.96 & 51.00 & 113.00 & 44 \\
& Height (m) & 1.67 & 0.06 & 1.54 & 1.80 & 44 \\
& BMI (kg m $\left.{ }^{-2}\right)$ & 26.30 & 5.25 & 17.86 & 43.06 & 44 \\
& Age (year) & 41.52 & 16.37 & 20.00 & 74.00 \\
\hline
\end{tabular}

Classification of overweight and obesity

\begin{tabular}{lcccccc}
\hline \multicolumn{1}{c}{ BMI $\left(\mathrm{kg} \mathrm{m}^{-2}\right)$} & Men & $\%$ & Women & $\%$ & Overall & $\%$ \\
\hline Less than 25 & 12 & 38.7 & 23 & 47.9 & 35 & 44.3 \\
25-30 (overweight) & 10 & 32.3 & 15 & 31.3 & 25 & 31.6 \\
30 and more (obesity) & 9 & 29.0 & 10 & 20.8 & 19 & 24.1 \\
\hline
\end{tabular}

The average age of people was 40.08 years and the mean of BMI was $26.04 \mathrm{~kg} \mathrm{~m}^{-2}$ (79 reviews people). For persons who have reached the minimum age of 20 years the average age of 44.17 years was found and the mean of BMI was $26.97 \mathrm{~kg} \mathrm{~m}^{-2}$ (70 reviews people).

The age structure of the first group was very diverse. In the case of men it was from 2 to 79 years and in women from 2 to 74 years. The diverse age structure is justified from the standpoint of families and needed (existence of a joint analysis of one or two generations of ancestors).

According to our results, the age is not a limiting factor in the analysis of the relationship of BMI of the individual genes and polymorphisms. When comparing the body mass index of men (27.09) and women (25.37) of all subjects and average values of subjects who had at least 20 years (male 28.10 and female 26.30) was a difference of about only 1 point. In any case, since individual human body measurements are significantly affected by age, also the effect of age was taken into account.

The classification of persons according to the international classification of underweight, overweight and obesity are presented in Table 5.

Based on the classification of overweight and obesity we can conclude that, overall, $55.7 \%$ of people $(61.3 \%$ men and $52.1 \%$ women) we analyzed, suffer from overweight and obesity.

In a study conducted on a population of people in the US, it was reported an average BMI of $27.8 \mathrm{~kg} \mathrm{~m}^{-2}$ (Morland and Evenson 2008). Dukát et al. (2007) states that in Slovakia, the mean BMI is $26.94 \mathrm{~kg} \mathrm{~m}^{-2}$. In comparison with these values the first set of users have only a slightly lower mean BMI. Similar results were recorded in the first group of people by gender. When considering the minimum age of 20 years we find the mean BMI 26.97 virtually identical to the average for Slovakia.

\section{Molecular-genetic analysis of genes LEP (G2548A)}

Based on the genotyping group of people (79 people) gene LEP (G2548A) was analyzed in relation to obesity in humans based on BMI values with respect to gender and age.

In Figure 1 there are shown the results of DNA amplification section of the human leptin gene LEP (G2548A). To check the accuracy of the results and assess the purity of DNA we used positive and negative control samples.

Figure 1: Amplification of 242 bp DNA fragment for the human leptin gene of SNP mutation LEP G2548A

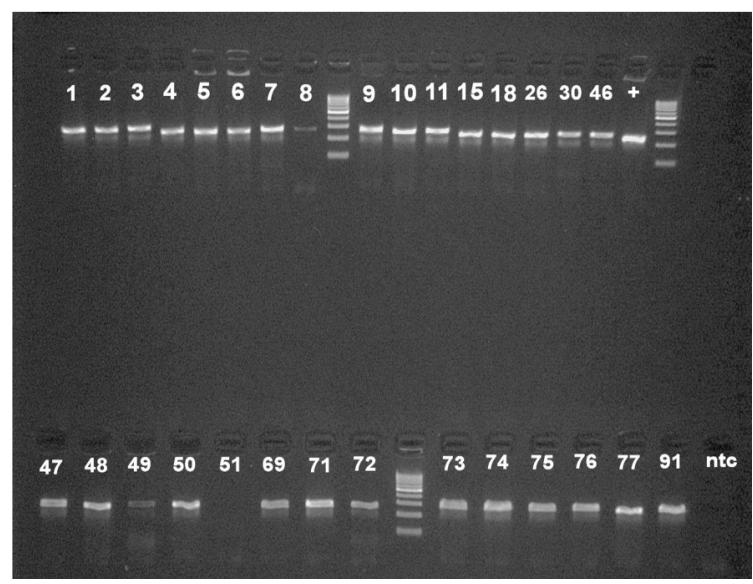

Note: + - positive control (human DNA isolated from blood with commercial kit), ntc - negative control (no template control - it has to be with no amplification fragment), positive samples - human DNA isolated from saline, used $100 \mathrm{bp}$ DNA ladder (Thermo Scientific)

The numbers above the results expresses the exact numbers of the examined samples. By number 51 we can see negative results cause of lack of DNA in this sample. 
In Figure 2 the image results of molecular genetic analysis of the PCR-RFLP for the detection of single nucleotide polymorphism G2548A are localized in the gene encoding the LEP adipocytokinine (protein), leptin. During the analysis, DNA ladder was used, based on were read count of base pairs.

\section{Figure 2: Gene LEP (G2548A)}

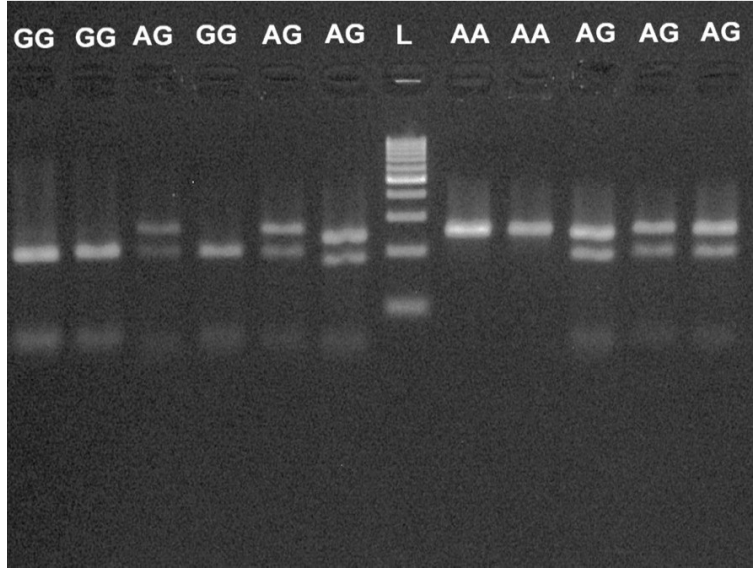

Note: AA - homozygote genotype (242 bp), AG - heterozygote genotype (242 bp+181 bp+61 bp), GG - homozygote genotype (181 bp+61 bp), L - 100 bp DNA ladder (Thermo Scientific)

\section{Statistical analysis of polymorphism of gene LEPR (G2548A)}

Basic statistical analysis of polymorphisms of individual genes we analyzed- are presented in Table 6. At LEP gene (G2548A) the most abundant genotype was AG (41 persons) and the least numerous genotype was AA (15 persons). 23 persons had identified genotype GG. The $\mathrm{G}$ allele frequency was 87 (64 persons) and the frequency of allele A was 71 (56 persons).

Testing frequencies of genotypes according to the Hardy-Weinberg law $\chi^{2}$-test confirmed the maintenance of equilibrium in the evaluated group of people.

\section{Analysis of the relationship of body mass index (BMI) and polymorphisms of genes}

Analysis of the relation of body mass index, and the gene polymorphism of the LEP was made from a linear model [1] referred in the methodology of the thesis.

The average BMI in relation to age highlighted differences in BMI in different genotypes in the gene LEP $\left(\mathrm{AA}=23.74 \mathrm{~kg} \mathrm{~m}^{-2}, \mathrm{AG}=26.48 \mathrm{~kg} \mathrm{~m}^{-2}, \mathrm{GG}=\right.$ $\left.27.32 \mathrm{~kg} \mathrm{~m}^{-2}\right)$ as opposed to values if we do not take into account the age of participants $\left(\mathrm{AA}=25.50 \mathrm{~kg} \mathrm{~m}^{-2}\right.$, $\mathrm{AG}=25.73 \mathrm{~kg} \mathrm{~m}^{-2}, \mathrm{GG}=26.94 \mathrm{~kg} \mathrm{~m}^{-2}$ ). The reduction in BMI when age was taken into account was stronger when genotype AA occurred.

Multiplicity and frequency of genotypes and alleles of the gene LEP

\begin{tabular}{|c|c|c|c|c|c|c|c|c|}
\hline \multirow{2}{*}{ Gene } & \multirow{2}{*}{ Genotype } & \multirow{2}{*}{ Count } & \multicolumn{3}{|c|}{ Frequencies } & \multirow{2}{*}{ PIC } & \multirow{2}{*}{ Het. } & \multirow{2}{*}{$\chi^{2}$-test } \\
\hline & & & Genotype & $\mathrm{All}$ & & & & \\
\hline \multirow{3}{*}{ LEP G2548A } & AA & 15 & 0.1899 & $\mathrm{~A}$ & $\mathrm{G}$ & \multirow{3}{*}{0.3724} & \multirow{3}{*}{0.5190} & \multirow{3}{*}{0.1876} \\
\hline & AG & 41 & 0.5190 & \multirow{2}{*}{$0.4494 \pm 0.0386$} & \multirow{2}{*}{$0.5506 \pm 0.0386$} & & & \\
\hline & GG & 23 & 0.2911 & & & & & \\
\hline
\end{tabular}

\section{DISCUSSION}

Riestra et al. (2010) also found that carriers of AA alleles had significantly lower BMI compared with GG genotype carriers. Overall, the frequency of allele $A$ is in obese girls lower $(p=0.032)$. The distribution of individual genotypes was as follows: $\mathrm{AA}=17.7 \%, \mathrm{GG}=$ $33.0 \%, \mathrm{AG}=49.3 \%$. Allele $\mathrm{A}=42.4 \%$. Compared with our results, we can find a few differences (Table 7).

Table 7

The frequency of risk alleles within the qualification of overweight and obesity

\begin{tabular}{lc}
\hline \multicolumn{1}{c}{ BMI $\left(\mathrm{kg} \mathrm{m}^{-2}\right)$} & gene LEP allele G \\
\hline$<25$ & $51 \%$ \\
$25-30$ (overweight) & $56 \%$ \\
30 and more (obesity) & $61 \%$ \\
\hline
\end{tabular}

G2548A polymorphism LEP has also been studied in the population of indigenous people of Taiwan and it was found that people with extreme obesity $(\mathrm{BMI} \geq 35$ $\mathrm{kg} \mathrm{m}^{-2}$ ) have a higher frequency of GG genotype compared with those of normal weight $(6.9 \%)$, but not with people who were overweight on average (35>BMI $\geq 27 \mathrm{~kg} \mathrm{~m}^{-2}$ ) (Wang et al. 2006).

According to Okorodudu (2010), BMI values have not so high sensitivity for the determination of adiposity, since it does not recognize about half the people with excess body fat amount (\% BF), even if they have high specificity. Since BMI values do not take into account body fat $(\mathrm{BF} \%)$, we can considered determining obesity by BMI as approximate and if clarification is necessary, it is also needed to perform additional measurements. Increasingly, in relation to obesity begins to associate the waist to hip circumference (waist to hip ratio - WHR).

\section{CONCLUSIONS}

The results achieved in analysis of the relation of body mass index and polymorphisms of the studied gene allow us to confirm the hypothesis that the polymorphism of LEP gene is related to obesity expressed by human body mass index (BMI).

At LEP polymorphism (G2548A), the frequency of allele A was less common $(0.4494 \pm 0.0386)$ than $\mathrm{G}$ allele $(0.5506 \pm 0.0386)$, and most participants had 
heterozygous form of genotype AG (0.5190). From homozygous forms occurred more often form GG (0.2911), the least AA (0.1899).

Level of polymorphism at LEP was 0.3724 . Carriers of genotype AA in LEP polymorphism were observed with respect to age, on average, significantly lower BMI $\left(23.74 \mathrm{~kg} \mathrm{~m}^{-2}\right)$, compared with $\mathrm{GG}$ genotype carriers of BMI $\left(27.32 \mathrm{~kg} \mathrm{~m}^{-2}\right)$.

For a more comprehensive evaluation of polymorphisms studied genes and their impact on obesity, we suggest future conduct additional anthropometric measurements, blood tests in connection with the nutritional history and in particular the extension samples of observed people.

\section{ACKNOWLEDGEMENT}

This paper presents the results obtained by the author for the research project: APVV-0636-11 Draft panels SNPs markers of physiological characteristics of farming animals for use in genomic evaluations.

\section{REFERENCES}

Ali, S. B.-Kallel, A.-Ftouhi, B.-Sediri, Y.-Feki, M.-Slimane, H.Jemaa, R.-Kaabachi, N. (2009): Association of G-2548A LEP polymorphism with plasma leptin levels in Tunisian obese patients. Clinical Biochemistry. 42: 584-588.

Constantin, A .-Costache, G.-Sima, A.V.-Glavce, C. S.-Vladica, M.-Popov, D. L. (2010): Leptin G-2548A and leptin receptor Q223R gene polymorphisms are not associated with obesity in Romanian subjects. In Biochemical and Biophysical Res. Commun. 391: 282-286.

Deeparani, T.-Radhakrishna Pllai, M.-Elavazhagan, T. (2009): Detection of MTHFR C677T and A1298C gene polymorphism in congenital heart disease. Middle-East Journal of Scientific Research. 4: 127-132.

Dukát, A.-Lietava, J.-Krahulec, B.-Čaprnda, M.-Vacula, I.-Sirotiaková, J.-Kosmálová, V.-Minárik, P. (2007): Prevalencia abdominálnej obezity na Slovensku, Štúdia IDEA Slovakia. Vnitřní Lékařství. 53. 4: 326-330.

Fourati, M.-Mnif, M.-Kharrat, N.-Charfi, N.-Kammoun, M.Fendri, N.-Sessi, S.-Abid, M.-Rebai, A.-Fakhfakh, F. (2013): Association between Leptin gene polymorphisms and plasma leptin level in three consanguineous families with obesity. Gene. 527: 75-81.

Kumar, S.-Raju, M.-Gowda, N. (2010): Influence of Parental Obesity on School Children. Indian Journal of Pediatrics. 77: 255-258.

Kunešová, M.-Hlubik, P.-Hainer, V.-Býma, S. (2005): Obezita Doporučený diagnostický a léčebný postup pro všeobené praktické lékaře. Praha: Společnost všeobecného lékařství ČLS JEP s. 1.

Lemas, D. J.-Klimentidis, Y. C.-Wiener, H. H.-O'Brien, D. M.Hopkins, S. E.-Allison, D. B.-Fernandez, J. R.-Tiwari, H. K.Boyer, B. B. (2013): Obesity polymorphisms identified in genomewide association studies interact with n-3 polyunsaturated fatty acid intake and modify the genetic association with adiposity phenotypes in Yup'ik people. Genes and Nutrition. 8: 495-505.
Mammès, O.-Betoulle, D.-Aubert, R.-Herbeth, B.-Siest, G.Fumeron, F. (2000): Associacion of the G-2548A polymorphism in the 5' region of the LEP gene with overweight. Annals of Human Genetics. 64: 391-394.

Morland, K. B.-Evenson, K. R. (2008): Obesity prevalence and the local food environment. Health Place. Vol.15.

Nei, M. (1978): Estimation of average heterozygosty and genetic distance from a small number of individuals. Genetics. 89: 583-590.

Nyin Ang, Y.-Wee, B. S.-Koon Poh, B.-Ismail, M. N. (2012): Multifactorial influences of childhood obesity. Current Obesity Reports. 2: 10-22.

Okorodudu, D. O.--Jumean, M. F.-Montori, V. M.-Romero-Corral, A.Somers, V. K.-Erwin, P. J.-Lopez-Jimenez, F. (2010): Diagnostic performance of body mass index to identify obesity as defined by body adiposity: a systematic review and meta-analysis. International Journal of Obesity. 34: 791-799.

Paquot, N.-De Flines, J.-Rorive, M. (2012): Obesity: a model of complex interactions between genetics and environment. Revue Médicale de Liège. 67: 332-336.

Riestra, P.-Garcia-Anguita, A.-Viturro, E.-Schoppen, S.-De Oya, M.-Garcés, C. (2010): Influence of the leptin G-2548A polymorphism on leptin levels and anthropometric measurements in healthy Spanish adolescents. Annals of Human Genetics. 74: 335-339.

Wang, T. N.-Huang, M. C.-Chang, W. T.-Ko, A. M. S.-Tsai, E. M.Liu, C. S.-Lee, C. H.-Ko, Y. C. (2006): G-2548A Polymorphism of the Leptin Gene Is Correlated with Extreme Obesity in Taiwanese Aborigines. Obesity. 14: 183-187. 